Article

\title{
Synthesis, antioxidant, anticholinesterase activities and molecular docking studies of coumaryl 1,3- selenazoles derivatives
}

\author{
Nurul Zawani Alias1, Muhd Hanis Md Idris², Nurhafizoh Abdul Somat ${ }^{3}$, Norwaziah Mahmud4, \\ Sharizal Hasan', Lam Kok Wai ${ }^{5}$, Azwan Mat Lazim ${ }^{6}$ and Nurul Izzaty Hassan ${ }^{6 *}$ \\ 1 Faculty of Applied Sciences, Universiti Teknologi MARA (UiTM) Perlis, 02600 Arau, Perlis, Malaysia ; \\ zawani299@perlis.uitm.edu.my, sharizal187@uitm.edu.my \\ 2 Integrative Pharmacogenomics Institute (iPromise), Universiti Teknologi MARA (UiTM) Selangor, Puncak \\ Alam Campus, 42300 Bandar Puncak Alam, Selangor, Malaysia; muhd_hanis@hotmail.com \\ 3 Atta-ur-Rahman Institute for Natural Product Discovery, Universiti Teknologi MARA (UiTM) Selangor, \\ Puncak Alam Campus, 42300 Bandar Puncak Alam, Selangor, Malaysia; norhafizoh_abdulsomat@yahoo.com \\ 4 Faculty of Computer and Ma the matical Sciences, Universiti Teknologi MARA (UiTM) Perlis, 02600 Arau, \\ Perlis, Malaysia;norwaziah@uitm.edu.my \\ 5 Drugs and Herbal Rese arch Centre, Fa culty of Pharma cy, Universiti Kebangsaan Ma laysia, Jalan Raja Muda \\ Abdul Aziz, 50300 Kuala Lumpur, Malaysia; david_lam@ukm.edu.my \\ 6 Department of Che mical Sciences, Fa culty of Science \& Technology, Universiti Kebangsaan Malaysia, 43600 \\ Bangi, Selangor, Malaysia; e-mail@e-mail.com \\ * Correspondence: drizz@ukm.edu.my; Tel.:+603-89213878
}

\begin{abstract}
Inhibition of acetylcholinesterase (AChE) enzyme is a known procedure to treat severe Alzheimer's disease through increasing the acetylcholine level in the brain and thus slowing down the progression of Alzheimer's symptoms. The approved medications are only considered as palliative and addressed some reported deficiencies. Therefore, the demand for safe and effective compounds is substantially increasing. A newly series of coumaryl 1,3-selenazoles derivatives was synthesized in four steps. Then, their antioxidant activities were evaluated using DPPH, ABTS cation radical scavenging assay and cupric reducing antioxidant capacities (CUPRAC). The anticholinesterase activities were evaluated using the Ellman method. Then, the docking studies were carried out to explain the possible correlation between in vitro anticholinesterase activity results and the ligand-receptor interactions. Ten new coumaryl 1,3-selenazoles (5a-5d series and $\mathbf{6 a - 6} \mathbf{f}$ series) derivatives were successfully synthesized. The DPPH radical scavenging assay show ed that all tested compounds have IC $\mathrm{C}_{50}$ value $>200 \mu \mathrm{M}$, for ABTS cation radical scavenging assay the $\mathrm{IC}_{50}$ value $>1000$ $\mu \mathrm{M}$ and for CUPRAC assay the IC 50 value $>200 \mu \mathrm{M}$. Compound $\mathbf{5 c}$ w as found to be the most active compound against $\mathrm{AChE}$ and $\mathrm{BChE}$ in its series with IC 50 value for $\mathrm{AChE}$ is $99.76 \mu \mathrm{M}$ and $\mathrm{IC}_{50}$ for BChE is $140.28 \mu \mathrm{M}$ while $6 \mathrm{~b}$ exhibited the most potent inhibition in its series with IC50 value for AChE is $56.01 \mu \mathrm{M}$ and $\mathrm{IC}_{50}$ for BChE is $121.34 \mu \mathrm{M}$. Besides, the docking studies showed that compound $5 \mathrm{c}$ and $\mathbf{6 b}$ formed $\pi-\pi$ stacking interaction with aromatic residues at the active site of $\mathrm{AChE}$ and $\mathrm{BChE}$, which is responsible for inhibiting the enzymes. This shows that the synthesized compounds contain skeletal structures that can interact and inhibit within the enzymes active site.
\end{abstract}

Keywords: acetylcholinesterase; antioxidant; Alzheimer; coumarin; selenazole

\section{Introduction}

Alzheimer is categorized as a dementia disease which prominently attacks the elderly aged between 65 years and above [1,2]. Generally, Alzheimer patients will experience loss of memory that is accompanied by cognitive deterioration - a deteriorating in the ability to think and learn which 
contributed to the difficulty in speaking and walking, henceforth these drawbacks conceivably lead to death $[1,3,4]$. Among elderly patients attending medical clinics in Universiti Kebangsaan Malaysia Medical Centre, the prevalence of mild cognitive impairment was apparent and is believed to be a precursor to Alzheimer disease [5] Three main factors affect Alzheimer disease, including a decrease of acetylcholine level, formation of $\beta$-amyloid plaque and the digression of neurofibrillary in human brain $[3,4,6]$. In addition, oxidative stress plays a crucial role in the pathogeny of Alzheimer's disease $[7,8]$. Nevertheless, consideration of the underlying factors and the progressions of this disease have not been fully understood [9-11]. Notably, four acetylcholinesterase (AChE) inhibitors have been commercially used, namely tacrine $\left(\right.$ Cognex $($ ) , rivastigmine (Exelon $\AA)$, donepezil (Aricept ${ }^{\circledR}$ ) and galantamine (Razadyne ${ }^{\circledR}$ ) (Fig 1). Apart from that memantine, N-methyl-D-aspartate(NMDA) receptor agonist, has also been employed to moderate Alzheimer's disease in mitigating additional neurological conditions by acting as neuroprotective agent that positively impacts both neurodegenerative and vascular processes $[2,12-14]$.<smiles>Nc1c2c(nc3ccccc13)CCCC2</smiles>

1

(Tacrine)<smiles>CCN(C)C(=O)Oc1cccc(C(C)N(C)C)c1</smiles>

2

(Rivastigmine)<smiles>COc1cc2c(cc1OC)C(=O)C(CC1CCN(Cc3ccccc3)CC1)C2</smiles>

3

(Donepezil)<smiles>COc1ccc2c3c1OC1CC(O)C=CC31CCN(C)C2</smiles>

4

(Galantamine)<smiles>CC12CCC(C)(CC(N)C1)C2</smiles>

5

(Memantine)

Figure 1. Structures of well-known choline ste rase inhibitors.

Tacrine w as the first AChE inhibitor that has been approved in 1993, but the usage w as withdrawn because of highly toxic to the liver and demonstrated low bioavailability [13,14]. In 1996, another AChE inhibitor namely donepezil w as approved for Alzheimer's treatment. Donepezil is reversible and highly active with low toxicity. Galantamine - an alkaloid compound found in Galanthus woronaii species and Amaryllidaceae family, is the only AChE inhibitor derived from natural products. This reversible alkaloid is highly competitive and is a selective AChE inhibitor. The treatment with galantamine potentially showed good results, but thus far, itless effective than tacrine.

Due to complex structure, the synthesis of galantamine requires series of prolonged passive reactions [14,15]. Conversely, rivastigmine is a pseudo-irreversible AChE inhibitor with a low er effect towards butyrylcholinesterase enzyme (BChE). It is noticeable that $\mathrm{BChE}$ is responsible for the hydrolysis of acetylcholine to choline by lowering the level of acetylcholine in the brain. Therefore, the inhibition of $\mathrm{BChE}$ also plays an essential role in the treatment of Alzheimer's disease. Further progress in AChE inhibitor drug discovery can be seen through the development of memantine - the last drug approved that acts through a different mechanism[[2,14]]. Despite the availability of these drugs, the 
remedies remain palliative with side effects, such as nausea, anorexia, vomiting and diarrhoea [16]. Therefore, there is a need to find a new potent AChE inhibitor with low toxicity effects. AChE has two binding sites, namely an anionic site of the catalyst and the peripheral anionic site that is linked by the spacer group. AChE inhibitors bind through one or both sites with the latter leading to the dual inhibitions of AChE. Thus, it is a considerable prospect to synthesize a compound that can interact with both sites for dual inhibition by linking two different moieties through an appropriate spacer.

The coumarin ring is a heterocyclic moiety that previously demonstrated to be a potential antiAChE and favourable by the optimal synthetic accessibility [17-19].Coumarin derivatives are also among various synthetic compounds that have been tested for AChE inhibitor $[17,20]$. The coumarin pharmacophore has been predicted as one of the moieties as this heterocyclic compound can form parallel and stable $\pi-\pi$ stacks on the active cataly tic site [3]. Other than that, coumarins in both natural and synthesized exhibit wide range of bioactivities including antioxidant which is essential to address one of the contributing factors of Alzheimer's disease that is oxidative stress [21-23]. The second moiety that can interact with the other active site is the benzyl amino group. Benzyl amino group was present in many potent $\mathrm{AChE}$ inhibitors and its binding capability at the cent re of $\mathrm{AChE}$ is demonstrated by the X-ray crystallographic studies of the AChE/donepezil and AChE/galantamine complexes [18]. Besides, previous systematic reviews found that the most potent AChE inhibitor comparable with rivastigmine possess benzyl amino group as one of its moieties [20].

In this study, selenazole ring and urea moiety were chosen as the spacer. Selenazole ring is an aromatic ring and may interact with the aromatic residues located at the AChE gorge through $\pi-\pi$ stacking [18]. Besides, selenazole ring was selected because of the presence of selenium, a known antioxidant that can reduce oxidative stress, which is a known factor of Alzheimer's disease [3,24,25]. While urea moiety was selected for its ability to form H-bonds, forming complexes and its devouring extensive biological activity [3]. Therefore, the combination of selenazole ring and urea as the spacer is predicted to increase the interaction with the residues lining, the wall of AChE gorge. Thus, the antioxidant activity of the compounds can be improved as a whole.

The new hybrid molecule with a modified coumarin structure obtained by replacing the thiazole ring with selenazole ring (blue coloured) was demonstrated (Scheme 1). This compound bears a resemblance of the potent AChE inhibitor, AP2238 [18]. A broad approach in determining the potential of 1,3-selenazole hybrid coumaryl compound as an AChE and BChE inhibitor via in vitro testing and molecular docking are also highlighted in this work. To the best of our knowledge, there is a limited study on the synthesis and biological activities of coumaryl 1,3- selenazole structures. This is a continuation of previous w ork on the synthesis of coumaryl1,3-selenazole derivatives and its biological activities and the crystal structure of a coumaryl1,3-selenazole $[23,26]$.<smiles>[X]C(Nc1cc[R]cc1)Nc1nc(-c2cc3cc[R]([H])cc3oc2=O)cs1</smiles>

$\mathrm{X}=\mathrm{O}, \mathrm{S}$

(Kurt et al. 2015)<smiles></smiles>

Target compounds 
Scheme 1. The design strategy of the targeted compounds which contain coumarin, benzyl a mino group, urea moiety and thiazole ring re placed by selenazole ring.

Synthesis of target compounds was performed according to the reaction sequence outlined in Scheme 2. Compounds $\mathbf{2 b - 2 e}$ were synthesized from salicylaldehydes following the protocol with minor modifications [27]. The salicylaldehy de $w$ as reacted $w i$ th ethyl acetoacetate $w$ ith piperidine as a base. This reaction is called Knoevenagel condensation, which results in the formation of a lactone ring and removal of water. Then, they were brominated with N-bromosuccinamide, NBS in chloroform: acetonitrile (20:4) in the presence of $p$-toluenesulfonic acid, PTSA as a catalyst and were refluxed for 4 hours to give compounds $3 \mathbf{b}-3 \mathbf{e}$ [28]. After that, 2-Amino-4-(coumarin-3-yl) selenazoles derivatives (4a4e) were obtained by the reactions of $3 \mathbf{a}-3 \mathbf{e}$ with selenourea in methanol: water (1:1) at room temperature with stirring and sodium fluoride as the catalyst $[23,29]$. Subsequently, compounds $4 \mathbf{a}-4 \mathbf{e}$ were refluxed with aryl isocy anates in dry THF using triethylamine as a base for $12 \mathrm{~h}$ to give coumaryl selenazoles containing urea derivatives (5a-5d) [3]. Alternatively, compounds $4 \mathbf{a}-\mathbf{4} \mathbf{e}$ w ere reacted with maleic anhydride in the presence of THF as the solvent for $3 \mathrm{~h}$ at room temperature to give maleamic acid derivatives (6a-6f). 
<smiles>[R2]c1cc([R7])c(O)c(C=O)c1</smiles>

1b-1e<smiles>[R2]c1cc([R])c2oc(=O)c(C(C)=O)cc2c1</smiles>

$2 b-2 e$

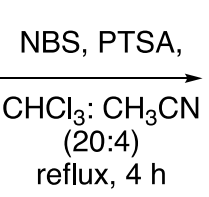

reflux, $4 \mathrm{~h}$<smiles>[R]c1cc([R])c2oc(=O)c(C(=O)CBr)cc2c1</smiles>

$3 a-3 e$

1b: $\mathrm{R}_{1}=\mathrm{CH}_{3}, \mathrm{R}_{2}=\mathrm{H}$

1c: $\mathrm{R}_{1}=\mathrm{Br}, \mathrm{R}_{2}=\mathrm{Br}$

1d: $\mathrm{R}_{1}=\mathrm{Cl}, \mathrm{R}_{2}=\mathrm{Cl}$

1e: $\mathrm{R}_{1}=\mathrm{OCH}_{3}, \mathrm{R}_{2}=\mathrm{H}$<smiles>[R]c1cc([R])c2oc(=O)c(-c3coc(NC(=O)Nc4ccccc4[R5])n3)cc2c1</smiles>

5a-5d

5a: $R_{1}=R_{2}=H, R_{3}=C l$

5b: $R_{1}=R_{2}=H, R_{3}=B r$

5c: $R_{1}=\mathrm{CH}_{3}, \mathrm{R}_{2}=\mathrm{H}, \mathrm{R}_{3}=\mathrm{Br}$

5d: $R_{1}=R_{2}=H, R_{3}=N_{2}$

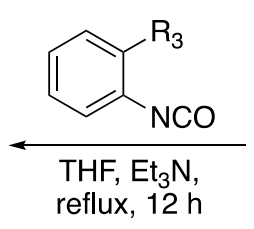<smiles>[R]c1cc(Br)c2oc(=O)c(-c3c[se]c(N)n3)cc2c1</smiles>

4a-4e<smiles>[X]C1=C([X])C(=O)OC1=O</smiles><smiles>[X]C(C(=O)O)=C([X])C(=O)Nc1nc(-c2cc3cc([R])cc([R7])c3oc2=O)c[se]1</smiles>

$6 a-6 f$

Scheme 2. Synthesis of new substituted coumaryl 1,3-selenazole de rivatives.

\section{Results}

\subsection{Materials and Methods}

All the new compounds were characterized by ${ }^{1} \mathrm{H}$ NMR, ${ }^{13} \mathrm{C}$ NMR, IR and electron spray ionization-mass spectrometry. In the infrared spectra of the synthesized compounds, it w as possible to observe the absorption 2400-3400 $\mathrm{cm}^{-1}$ for OH group of carboxylic acid for maleamic acid derivatives. Absorption between 3231 and $3488 \mathrm{~cm}^{-1}$ observed related to NH stretch of urea derivatives while between 3180 and $3300 \mathrm{~cm}^{-1}$ recorded for maleamic acid derivatives. The absorption betw een 1524 and $1566 \mathrm{~cm}^{-1}$ corresponded to the $\mathrm{C}=\mathrm{N}$ stretch for selenazole for both derivatives. The absorption for the 
$\mathrm{C}=\mathrm{O}$ group was observed between 1725 and $1737 \mathrm{~cm}^{-1}$ from coumarin carbonyl moiety stretch and between 1692 and 1702 for urea carbonyl moiety stretching. The maleamic acid derivatives had three absorptions for $\mathrm{C}=\mathrm{O}$ group observed between 1641 and $1739 \mathrm{~cm}^{-1}$ representing the carbonyl group for carboxylic acid, coumarin and amide groups.

From the ${ }^{1} \mathrm{H}$ NMR spectrum, two signals due to the hydrogen attached to the amide nitrogen were observed at 8.26 and $10.67 \mathrm{ppm}$ for urea derivatives for compound $\mathbf{5 a}$. The only proton at selenazole ring $w$ as detected at $8.60 \mathrm{ppm}$. This result is supported by the literature data [[30]]. The signals for the vinyl proton of maleamic acid derivatives, $6 \mathrm{a}$ w as observed at 6.51 and $6.56 \mathrm{ppm}$. From the ${ }^{13} \mathrm{C}$ NMR, the signal at 157.2 to $159.4 \mathrm{ppm}$ w as assigned to the coumarin carbonyl for both derivatives, $5 \mathrm{a}-5 \mathrm{~d}$ and 6a-6f.

On the other hand, the signal at 151.4 to $151.8 \mathrm{ppm}$ w as assigned to the carbonyl group for urea. The carbon at selenazole ring which attached to the urea or amide moiety is the most downfield signal observed at $160.3 \mathrm{ppm}$ for $\mathbf{5 a}$ and $167.7 \mathrm{ppm}$ for $\mathbf{6 a}$. The $\mathrm{C}=\mathrm{O}$ signal for amide and carboxylic acid for 6a-6f compounds were observed at 161.2 and $167.8 \mathrm{ppm}$, respectively.

\section{Discussion}

\subsection{Antioxidant activity assay}

\subsubsection{DPPH radical scavenging assay}

The 1,1-diphenylpicrylhydrazyl (DPPH) assay is a rapid, simple and inexpensive method which employs free radicals for the screening of antioxidant activity. As shown in Table 1, all synthesized compounds exhibit high IC 50 values for DPPH assay $(386.34-1675.71 \mu \mathrm{M})$ as compared to gallic acid $\left(\mathrm{IC}_{50}=9.09 \mu \mathrm{M}\right)$ and ascorbic acid $\left(\mathrm{IC}_{50}=28.43 \mu \mathrm{M}\right)$ as reference compounds. Target compounds $\mathbf{5 a}-\mathbf{5 c}$ exhibited IC $50>1000 \mu \mathrm{M}$ values indicating weak antioxidant activity.

\subsubsection{2,2'-Azino-bis(3-Ethylbenzothiazoline-6-Sulfonic Acid) (ABTS) cation radical scavenging assay}

The ABTS method is based on the ability of hydrogen or electron-donating antioxidants to decolourize the preformed radical monocation of 2,2'-azino-bis(3-ethylbenzthiazoline-6-sulfonic acid) (ABTS ${ }^{\bullet}$ ) generated due to the oxidation of ABTS with potassium persulfate. As depicted in Table 1, all tested compounds showed high IC50 values which are $>1000 \mu \mathrm{M}$. These values are higher than gallic acid $\left(\mathrm{IC}_{50}=795.72 \mu \mathrm{M}\right)$, which showed that all synthesized compounds exhibited weak antioxidant activity. The IC 50 values for target compound $\mathbf{5 a - 5}$ care higher than their sulfur analogue reported by Kurt et al. [[3]] which is $\mathrm{IC}_{50}=42.72-182.50 \mu \mathrm{M}$.

\subsubsection{Cupric Ion Reducing Antioxidant Capacity (CUPRAC) assay}

CUPRAC is a better antioxidant assay compared to other electron-transfer based assay due to its realistic $\mathrm{pH}$ close to physiological $\mathrm{pH}$, favourable redox potential, accessibility and stability of reagents and applicability to lipophilic antioxidants as well as hydrophilic ones. The CUPRAC assay of the synthesized compounds was determined as described previously using Trolox as the reference compound [31]. All synthesized compounds showed higher $\mathrm{A}_{0.50}$ values compared to Trolox ( $\mathrm{A}_{0.50}=$ 132.74 $\mu \mathrm{M}$ ). Compounds 5a-5c exhibited A0.50values $>1000 \mu \mathrm{M}$, which show ed that these compounds have weak antioxidant activity. 
Table 1. IC 50 and $A_{0.50}$ value $(\mu \mathrm{M})$ of compounds $4 \mathbf{a}-\mathbf{4 e}, \mathbf{5 a}-\mathbf{5 d}$ and $\mathbf{6 a}-\mathbf{6} \mathbf{f}$ for antioxidant activities

\begin{tabular}{cccc}
\hline Compound & DPPH IC $_{50}(\mu M)^{\mathbf{a}}$ & ABTS IC $_{50}(\mu M)^{\mathbf{a}}$ & $\begin{array}{c}\text { CUPRAC A }_{0.50} \\
(\boldsymbol{\mu M})^{\mathbf{b}}\end{array}$ \\
\hline $\mathbf{4 a}$ & $843.59 \pm 71.41$ & $1274.15 \pm 21.41$ & $288.16 \pm 12.26$ \\
$\mathbf{4 b}$ & $639.81 \pm 9.67$ & $1194.71 \pm 4.46$ & $315.76 \pm 18.25$ \\
$\mathbf{4 c}$ & $672.13 \pm 81.68$ & $1631.11 \pm 29.42$ & $465.72 \pm 35.07$ \\
$\mathbf{4 d}$ & $984.03 \pm 156.47$ & $1322.60 \pm 7.64$ & $299.93 \pm 9.79$ \\
$\mathbf{4 e}$ & $805.50 \pm 84.41$ & $3063.35 \pm 66.41$ & $531.26 \pm 21.40$ \\
$\mathbf{6 a}$ & $644.95 \pm 12.85$ & $2309.86 \pm 85.60$ & $321.29 \pm 8.03$ \\
$\mathbf{6 b}$ & $615.02 \pm 8.70$ & $1991.39 \pm 15.06$ & $404.42 \pm 7.70$ \\
$\mathbf{6 c}$ & $889.72 \pm 42.90$ & $1857.42 \pm 47.87$ & $366.01 \pm 14.65$ \\
$\mathbf{6 d}$ & $739.90 \pm 49.14$ & $2480.99 \pm 40.41$ & $297.72 \pm 4.73$ \\
$\mathbf{6 e}$ & $473.03 \pm 18.23$ & $1511.56 \pm 17.46$ & $279.20 \pm 14.72$ \\
$\mathbf{6 f}$ & $386.34 \pm 8.65$ & $1489.79 \pm 15.27$ & $341.30 \pm 10.67$ \\
$\mathbf{5 a}$ & $1675.71 \pm 21.29$ & $3524.34 \pm 908.68$ & $1628.42 \pm 235.02$ \\
$\mathbf{5 b}$ & $1462.24 \pm 55.09$ & $1632.44 \pm 87.21$ & $2555.30 \pm 0.00$ \\
$\mathbf{5 c}$ & $1323.08 \pm 5.29$ & $2421.30 \pm 114.55$ & $1000.31 \pm 100.53$ \\
$\mathbf{5 d}$ & $\mathrm{ND}$ & $\mathrm{ND}$ & $\mathrm{ND}$ \\
Gallic acid & $9.09 \pm 0.15$ & $795.72 \pm 1.32$ & - \\
Ascorbic acid & $28.43 \pm 1.52$ & - & - \\
Trolox & - & - & $132.74 \pm 5.46$ \\
\hline
\end{tabular}

a IC 50 values represent the means \pm SEM of three parallel measurements

b A 0.50 represent the means \pm SEM of three parallel measurements

$\mathrm{ND}=$ Not determined

\subsection{AChE and BChE inhibitory activities}

AChE and BChE inhibitory activities of the compounds determined based on the work of Jamila et al. [32] by employing physostigmine as the reference compound. $\mathrm{IC}_{50}$ values of $\mathrm{AChE}$ and BChE inhibitions are summarized in Table 2. Overall, the results indicated that most of the compounds exhibited moderate inhibition against both enzymes. The $\mathrm{IC}_{50}$ values of the compounds were recorded between 56.01 and $221.35 \mu \mathrm{M}$ for AChE inhibition assay. Meanwhile, the range of IC 50 value for the compounds in the BChE inhibitory assay was found between 121.34 and $311.37 \mu \mathrm{M}$. The selectivity index showed that all the compounds tested were not selective towards AChE or BChE. However, statistical differences in $\mathrm{AChE}$ and $\mathrm{BChE}$ activities were detected for all test compounds except for compound $5 \mathrm{c}$.

Among the compounds tested, $\mathbf{5 c}$ and $\mathbf{6 b}$ showed an $\mathrm{IC}_{50} \mathrm{AChE}<100 \mu \mathrm{M}$. Both compounds also showed the lowest $\mathrm{IC}_{50}$ for $\mathrm{BChE}$ in its series although it exceeded $100 \mu \mathrm{M}$. These results show that methyl group $\left(-\mathrm{CH}_{3}\right)$ at $\mathrm{C}-8$ at coumarin ring contributes to inhibiting $\mathrm{AChE}$ and $\mathrm{BChE}$. Nevertheless, Fig. 2 clearly shows that all tested compounds exhibit higher IC 50 value than standard AChE inhibitor which is physostigmine $\mathrm{IC}_{50} \mathrm{AChE}=0.17 \mu \mathrm{M}, \mathrm{IC}_{50} \mathrm{BChE}=0.59 \mu \mathrm{M}$, donepezil IC $\mathrm{C}_{50} \mathrm{AChE}=0.03 \mu \mathrm{M}$, $\mathrm{IC}_{50} \mathrm{BChE}=4.66 \mu \mathrm{M}$ and tacrine $\mathrm{IC}_{50} \mathrm{AChE}=0.086 \mu \mathrm{M}, \mathrm{IC}_{50} \mathrm{BChE}=0.013 \mu \mathrm{M}$.

The IC50 value for AChE increased from $124.12 \mu \mathrm{M}$ to $183.74 \mu \mathrm{M}$ when $\mathrm{Cl}$ (compound $\mathbf{5 a}$ ) is substituted with $\mathrm{Br}$ (compound $\mathbf{5 b}$ ) at $\mathrm{C}-16$. The increment showed that $\mathbf{5 b}$ has lower inhibition 
potency. This observation differs from Kurt et al. [3] which reported that a larger substituent on a phenyl ring exhibits better inhibition activity. The addition of two $\mathrm{Cl}$ atom at C-15 and C-16 in compound $6 \mathrm{f}$ caused a decrease in $\mathrm{IC}_{50}$ value for $\mathrm{AChE}$ and an increase in $\mathrm{IC}_{50}$ value for $\mathrm{BChE}$ as compared to compound $\mathbf{6 a}$ which does not contain a $\mathrm{Cl}$ atom in its structure. Compound $\mathbf{6} \mathbf{d}$ and $\mathbf{6} \mathbf{f}$ have the same molecular w eight because both compounds contain two $\mathrm{Cl}$ atoms but located at different carbon atoms. Modification of $\mathrm{Cl}$ atom position from the coumarin ring (6d) to C-15 and C-16 (6f) caused a drastic decrease in $\mathrm{IC}_{50} \mathrm{BChE}$. This show s that the $\mathrm{Cl}$ atom is more suitable as a substituent at C-15 than C-16 for BChE inhibition. The Kurt's sulfur analogue [3], compound 5 series with the same skeletal structure gives IC 50 values between 31.46 and $>200 \mu \mathrm{M}$ for AChE, while the IC50 values for $\mathrm{BChE}$ are between 4.93 and $194.55 \mu \mathrm{M}$. This showed that the substitution of the 1,3-selenazole moiety did not exhibit any differences in inhibition activity of AChE and BChE as compared to 1,3-thiazole moiety reported by Kurt et al. [3]. This is probably because the synthesized compounds are bigger than previous work as it contains selenium atom which has bigger atomic size than sulfur making it challenging to bind in the binding pocket of $\mathrm{AChE}[3,20]$.

Table 2. IC50 values $(\mu \mathrm{M})$ of compounds $4 \mathrm{a}-4 \mathrm{e}, 5 \mathrm{a}-5 \mathrm{~d}$ dan $6 \mathrm{a}-6 \mathrm{f}$ for $\mathrm{AChE}$ and $\mathrm{BChE}$.

\begin{tabular}{|c|c|c|c|c|c|}
\hline \multirow[t]{2}{*}{ Compound } & \multirow{2}{*}{$\begin{array}{c}\text { AChE IC }_{50} \\
(\mu M)^{a}\end{array}$} & \multirow{2}{*}{$\begin{array}{c}\text { BChE IC }_{50} \\
(\mu \mathrm{M})^{\mathrm{a}}\end{array}$} & \multirow[t]{2}{*}{$P$ value ${ }^{b}$} & \multicolumn{2}{|c|}{ Selectivity index } \\
\hline & & & & $\mathrm{AChE}^{\mathrm{c}}$ & $B C h E^{d}$ \\
\hline $4 a$ & ND & ND & - & - & - \\
\hline $4 b$ & ND & ND & - & - & - \\
\hline $4 c$ & ND & ND & - & - & - \\
\hline $4 d$ & ND & ND & - & - & - \\
\hline $4 e$ & ND & ND & - & - & - \\
\hline $6 a$ & $221.35 \pm 2.96$ & $159.37 \pm 13.46$ & $<0.05$ & 0.72 & 1.39 \\
\hline $6 b$ & $56.01 \pm 3.16$ & $121.34 \pm 2.19$ & $<0.05$ & 2.17 & 0.46 \\
\hline $6 c$ & ND & ND & & - & - \\
\hline $6 d$ & $190.43 \pm 19.50$ & $311.37 \pm 19.22$ & $<0.05$ & 1.64 & 0.61 \\
\hline $6 e$ & ND & ND & & - & - \\
\hline $6 f$ & $177.83 \pm 5.03$ & $214.34 \pm 4.80$ & $<0.05$ & 1.21 & 0.83 \\
\hline $5 a$ & $124.12 \pm 3.12$ & $282.50 \pm 15.30$ & $<0.05$ & 2.28 & 0.44 \\
\hline $5 b$ & $183.74 \pm 5.61$ & ND & $<0.05$ & - & - \\
\hline $5 c$ & $99.76 \pm 3.34$ & $140.28 \pm 23.32$ & 0.092 & 1.41 & 0.71 \\
\hline $5 d$ & ND & ND & - & - & - \\
\hline $\begin{array}{l}\text { Positive control } \\
\text { (physostigmine) }\end{array}$ & $10.12 \pm 2.19$ & $89.06 \pm 4.22$ & - & 8.80 & 0.11 \\
\hline Physostigmine & 0.17 & 0.59 & - & 3.47 & 0.29 \\
\hline Donepezil $^{\mathrm{f}}$ & $0.03 \pm 0.0005$ & $4.66 \pm 0.503$ & - & 155.33 & 0.006 \\
\hline Tacrine $^{f}$ & $0.086 \pm 0.0049$ & $0.013 \pm 0.001$ & - & 0.15 & 6.62 \\
\hline
\end{tabular}

a IC50 values represent the means \pm S.E.M. of three parallel measurements

b $P$ value of one-way ANOVA or $t$ test

c Selectivity index for $\mathrm{AChE}=\mathrm{IC}_{50}(\mathrm{BChE}) / \mathrm{IC}_{50}(\mathrm{AChE})$

d Selectivity index for $\mathrm{BChE}=\mathrm{IC}_{50}(\mathrm{AChE}) / \mathrm{IC}_{50}(\mathrm{BChE})$

e Values obtained from the literature [33]

${ }^{\mathrm{f}}$ Values obtained from the literature [3]

ND $=$ Not determined 


\subsection{Docking studies and binding mode analysis}

The most active compounds, $\mathbf{5 c}$ and $\mathbf{6 b}$, were selected to further examined their binding modes in binding pockets of both cholinesterase while donepezil was used as a reference drug for the docking studies. Table 3 summarizes the XP GScore values and binding site interactions between compound $\mathbf{5 c}$, $\mathbf{6 b}$ and donepezil with AChE. In human acetylcholinesterase (hAChE), phenyl ring of donepezil formed $\pi-\pi$ stacking with $\operatorname{Trp} 286$ in the peripheral site of the active site and $\operatorname{Trp} 86$ in the choline-binding pocket of active site similar to previous studies [34]. Besides, the carbonyl group of donepezil formed H-bonding with Phe 295. Meanwhile, compounds $\mathbf{5} \mathbf{c}$ and $\mathbf{6 b}$ showed good binding score against hAChE, which were -10.1 and $-8.9 \mathrm{kcal} / \mathrm{mol}$ respectively.

However, the binding scores of both compounds were higher than donepezil $(-16.8 \mathrm{kcal} / \mathrm{mol})$. Interestingly, compound $5 \mathrm{c}$ was found to simultaneously interact $w$ ith the peripheral site and catalytic site (acyl binding pocket) of hAChE. The carbonyl group of lactone group capable of forming $\mathrm{H}-$ bonding with essential residue, Phe 295 at the acyl binding pocket which w as similar to donepezil. The binding interactions of compound $\mathbf{5} \mathbf{c}$ were further strengthened with the formation of parallel $\pi-\pi$ stacking between the phenyl ring of coumarin and Tyr 341 at the peripheral site (Figure 2). In contrast, compound $\mathbf{6 b}$ only showed interaction at the peripheral site. The lactone group formed parallel $\pi-\pi$ stacking with Tyr 341 while C=O of carboxylic acid formed H-bonding with Tyr 124 (Figure 3).

Moreover, compound $\mathbf{6 b}$ fitted well in the gorge of hAChE as compared to compound $\mathbf{5 c}$, which did not fit as well. It was probably due to the presence of a large substituent group (Br) at the phenyl ring. Both compounds also exhibited $\pi-\pi$ stacking interactions with residues of AChE. However, this interaction did not involve $\operatorname{Tr} p 286$, a residue at the peripheral site, and $\operatorname{Tr} p$ 86, a residue at catalytic cleft which are crucial in achieving strong inhibitory effects by dual binding site inhibition.

Table 3. XP GS core values and binding interac tions between compound $5 \mathbf{c}, \mathbf{6 b}$ and donepezil with AChE (PDB: 4EY7).

\begin{tabular}{|c|c|c|c|c|c|}
\hline Compounds & $\begin{array}{c}\text { XP } \\
\text { GScore } \\
\text { (kcal/mol) }\end{array}$ & Active site & Residue & Moiety & Interaction \\
\hline \multirow[t]{2}{*}{$5 c$} & -10.1 & $\begin{array}{l}\text { Acyl binding } \\
\text { pocket }\end{array}$ & Phe 295 & $\mathrm{C}=\mathrm{O}$ lactone & H-bonding \\
\hline & & Peripheral site & Tyr 341 & $\begin{array}{l}\text { Coumarin } \\
\text { phenyl ring }\end{array}$ & $\pi-\pi$ stacking \\
\hline \multirow[t]{2}{*}{$6 b$} & -8.9 & Peripheral site & Tyr 341 & Lactone & $\pi-\pi$ stacking \\
\hline & & & Tyr 124 & $\begin{array}{c}\mathrm{C}=\mathrm{O} \\
\text { carboxylic } \\
\text { acid }\end{array}$ & H-bonding \\
\hline \multirow[t]{2}{*}{ Donepezil } & -16.8 & Peripheral site & $\operatorname{Trp} 286$ & Phenyl ring & $\pi-\pi$ stacking \\
\hline & & $\begin{array}{l}\text { Acyl binding } \\
\text { pocket }\end{array}$ & Phe 295 & $\mathrm{C}=\mathrm{O}$ & H-bonding \\
\hline
\end{tabular}


Choline binding Trp $86 \quad$ Phenyl ring $\pi-\pi$ stacking pocket
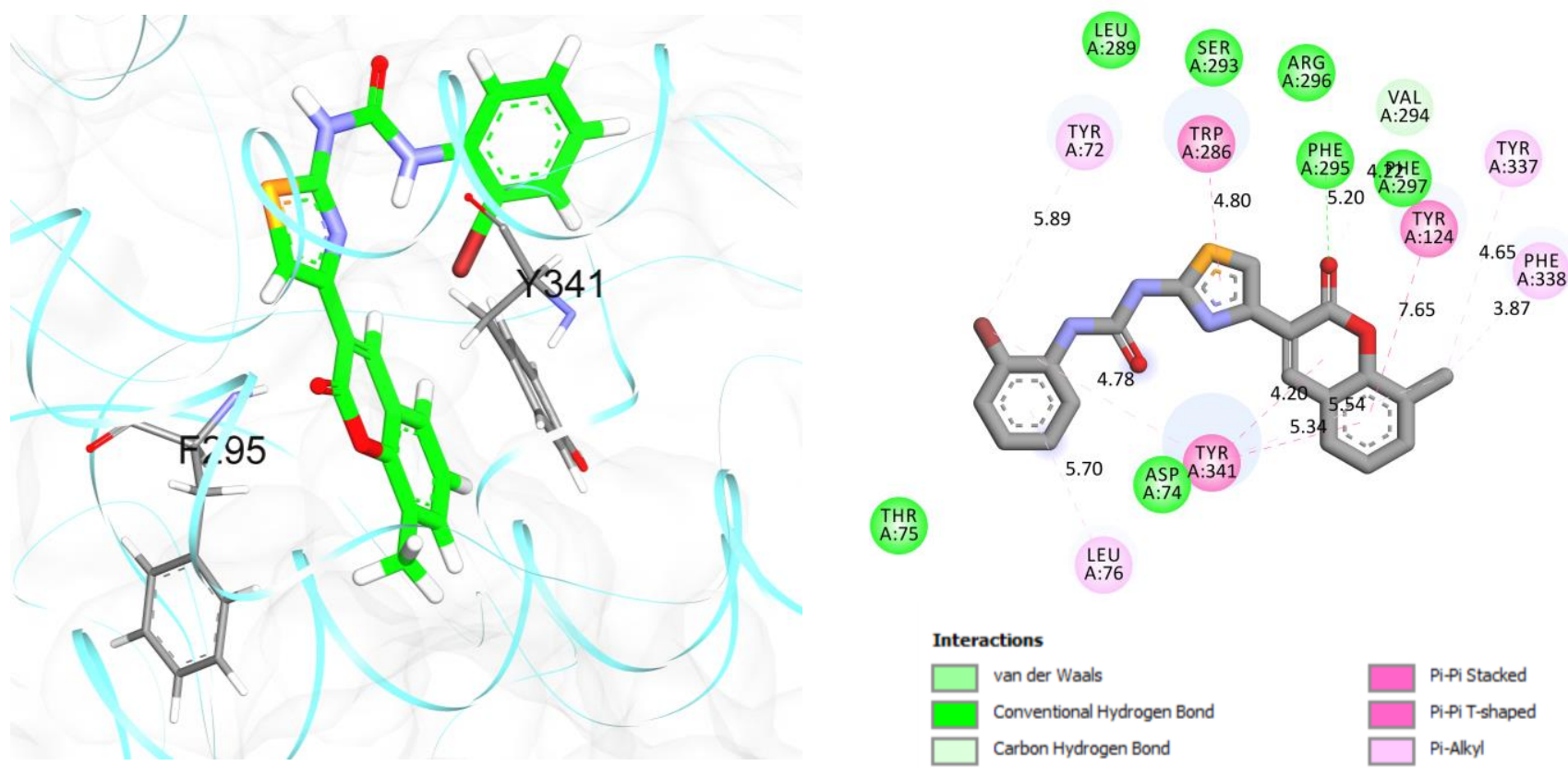

Figure 2. Binding interaction of compound $5 \mathrm{c}$ (orange) with the active site residues of hAChE at the gorge (grey surface). (should be printed in colour)
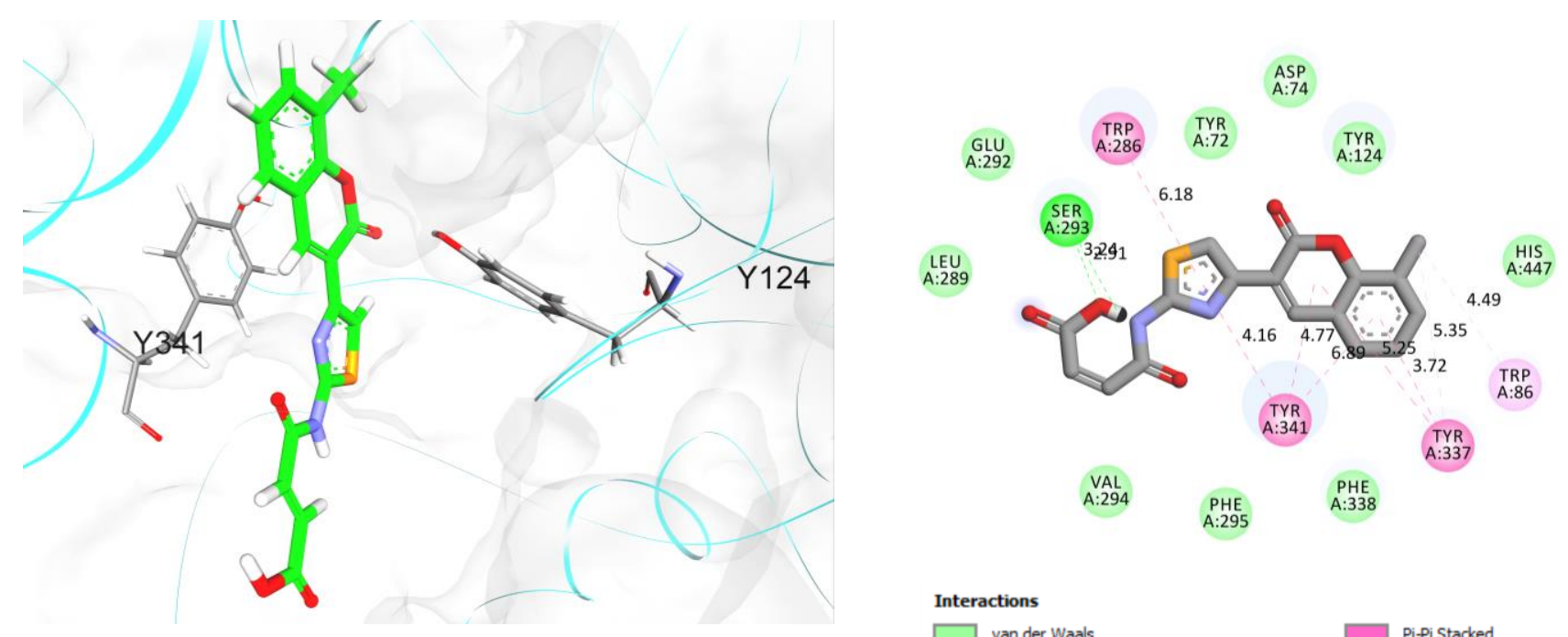

Interactions

van der Waals

Conventional Hydrogen Bond

Pi Pi Stacked

Pi-Alkyl 
Figure 3. Interaction of compound $\mathbf{6 b}$ (orange) with Tyr 341 and Tyr 124 at the peripheral site at the gorge of hAChE (grey surface). (should be printed in colour)

On the other hand, the binding scores for compounds $5 \mathbf{c}$ and $\mathbf{6 b}$ against hBChE were -6.6 dan -6.3 $\mathrm{kcal} / \mathrm{mol}$, respectively (Table 4). These values were slightly higher than the binding score of donepezil against $\mathrm{BChE}$, which was $-7.6 \mathrm{kcal} / \mathrm{mol}$. Both compounds show ed $\pi-\pi$ stacking with essential residues of hBChE [34]. Compound 5c exhibited T-shaped $\pi-\pi$ stacking between the coumarin phenyl ring and both Trp 231 and Phe 329 residues of the acyl binding pocket (Figure 4) while compound 6 b showed Tshaped $\pi-\pi$ stacking between the Tyr 332 residue and selenazole ring at the peripheral site (Figure 5). Donepezil showed simultaneous $\pi-\pi$ stacking at acyl binding pocket (Trp 231) and choline-binding pocket (Trp 82). The interaction with essential residues of hBChE which are Trp 231 and Trp 329 at acyl binding pocket, Tyr 332 at the peripheral site and Trp 82 at choline-binding pocket [35], suggested that compounds $\mathbf{5 c}$ and $\mathbf{6 b}$ can be considered as a potential BChE inhibitor.

Table 4. XP GScore values and binding interactions between compound 5c, $\mathbf{6 b}$ and done pe zil with AChE (PDB: 4EY7).

\begin{tabular}{|c|c|c|c|c|c|}
\hline Compounds & $\begin{array}{c}\text { XP } \\
\text { GScore } \\
\text { (kcal/mol) }\end{array}$ & Active site & Residue & Moiety & Interaction \\
\hline $5 c$ & -6.6 & $\begin{array}{l}\text { Acyl binding } \\
\text { pocket }\end{array}$ & $\begin{array}{l}\text { Trp } 231 \\
\text { Phe } 329\end{array}$ & $\begin{array}{l}\text { Coumarin } \\
\text { phenyl ring }\end{array}$ & $\pi-\pi$ stacking \\
\hline $6 b$ & -6.3 & Peripheral site & Tyr 332 & $\begin{array}{c}\text { Selenazole } \\
\text { ring }\end{array}$ & $\pi-\pi$ stacking \\
\hline \multirow[t]{2}{*}{ Donepezil } & -7.6 & $\begin{array}{c}\text { Choline binding } \\
\text { pocket }\end{array}$ & $\operatorname{Trp} 82$ & Phenyl ring & $\begin{array}{c}\pi-\pi \\
\text { stacking }\end{array}$ \\
\hline & & $\begin{array}{c}\text { Acyl binding } \\
\text { pocket }\end{array}$ & $\operatorname{Trp} 231$ & Phenyl ring & $\begin{array}{c}\pi-\pi \\
\text { stacking }\end{array}$ \\
\hline
\end{tabular}



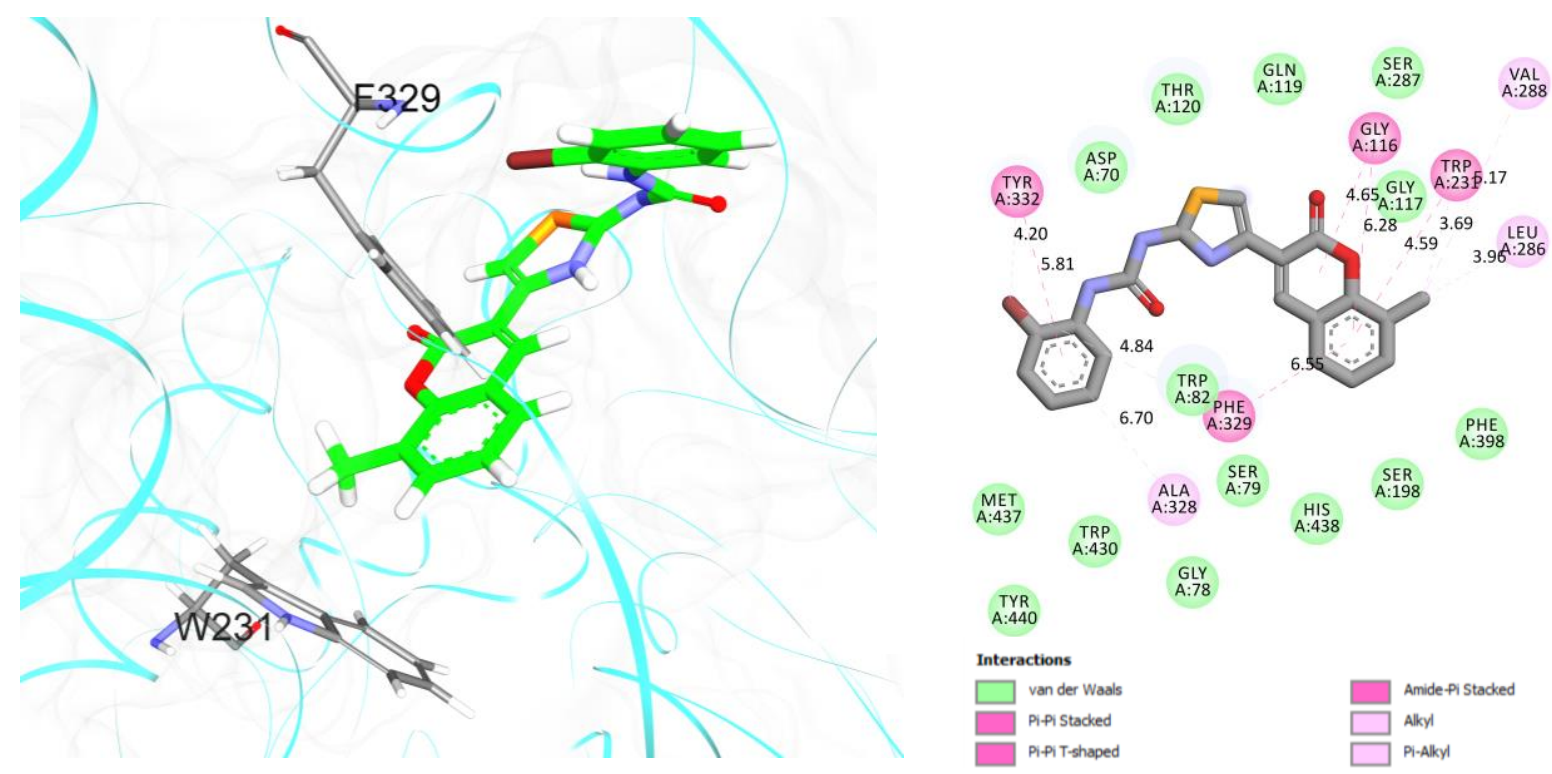

Figure 4. Interaction of compound 5c (orange) with Phe 329 and Trp 231 of a cylbinding pocket at the gorge of hBChE (grey surface). (should be printed in colour)
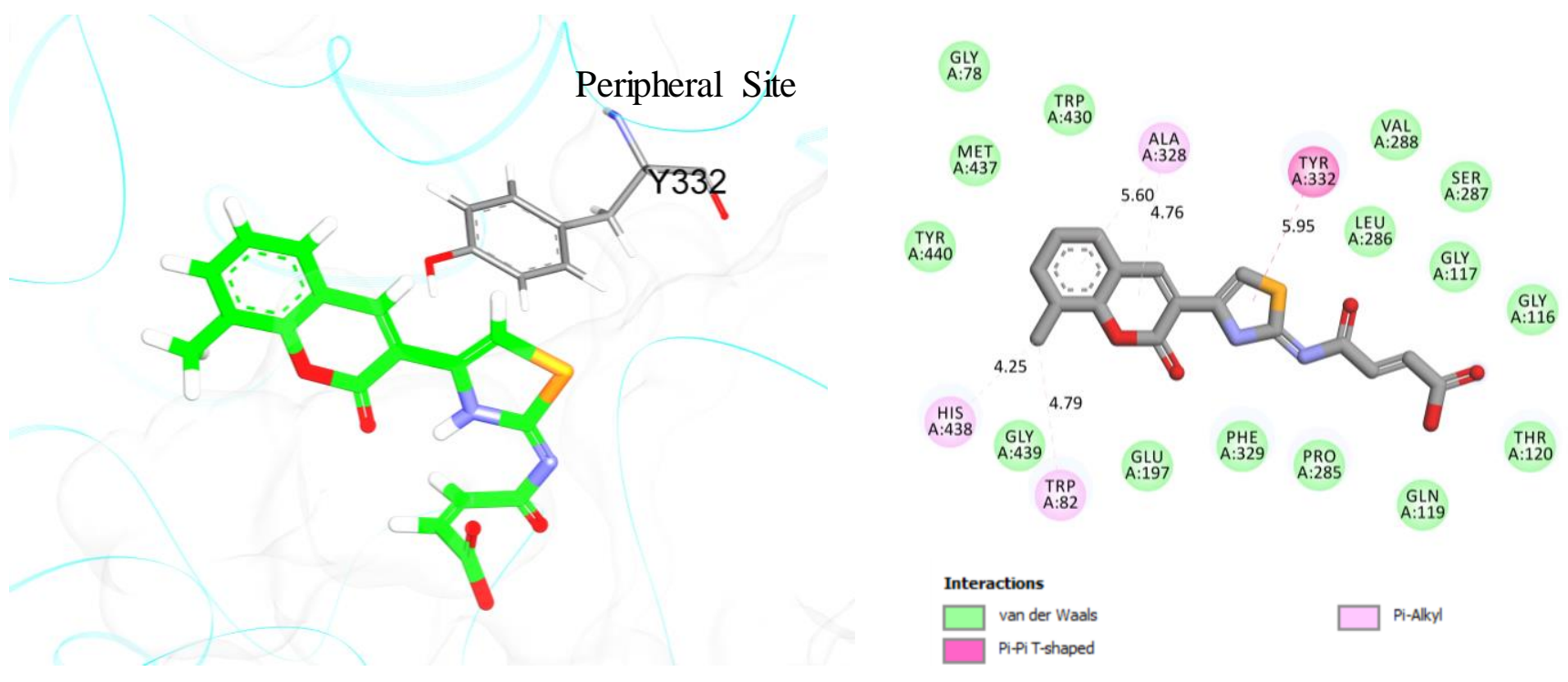

Figure 5 Interaction of compound $\mathbf{6 b}$ (orange) with Tyr 332 of the peripheral site at the gorge of hBChE (grey surface). (should be printed in colour) 


\subsection{ADMET profile of compounds $6 a-6 e$}

In general, all compounds exhibit a good level of human intestinal absorption and aqueous solubility. Table 5 summarizes the ADMET profiles for compounds 6a-6f. In addition, compounds 6a6b show low blood-brain barrier (BBB) penetration while the rest are undefined. In term of protein plasma binding properties capability, all the synthesized compounds are predicted to be binders. Further, all compounds are non-inhibitors to the cytochrome P450 2D6 enzyme. Finally, the in-silico prediction revealed that compounds $\mathbf{6 a - 6 e}$ are generally hepatotoxic. The intriguing results open further investigation for future works on improving the toxicity profile of the compounds.

Table 5. ADMET profile prediction of compounds 6a-e.

\begin{tabular}{|c|c|c|c|c|c|c|c|c|c|c|}
\hline \multirow{3}{*}{ Compound } & \multicolumn{10}{|c|}{ ADMET parameter } \\
\hline & \multicolumn{3}{|c|}{$\begin{array}{c}\text { Human Intestinal } \\
\text { Absorption }\end{array}$} & \multicolumn{2}{|c|}{$\begin{array}{l}\text { Aqueous } \\
\text { Solubility }\end{array}$} & \multicolumn{2}{|c|}{$\begin{array}{c}\text { Blood-Brain } \\
\text { Barrier (BBB) } \\
\text { Penetration }\end{array}$} & \multirow{2}{*}{$\begin{array}{c}\text { Plasma } \\
\text { Protein } \\
\text { Binding } \\
\text { (P P B) } \\
\text { Prediction }^{\mathrm{h}}\end{array}$} & \multirow{2}{*}{$\begin{array}{c}\text { Cytochrome } \\
\text { P } 450 \text { 2D6 } \\
\text { (CYP 2D6) } \\
\text { Prediction }^{\mathrm{i}}\end{array}$} & \multirow{2}{*}{$\begin{array}{c}\text { Hepatotoxicity } \\
\text { Predictioni }\end{array}$} \\
\hline & $\mathbf{P S A}^{\mathbf{a}}$ & ALogP98 & Level $^{\mathrm{c}}$ & $\log (S w)^{d}$ & Level $^{\mathrm{e}}$ & $\operatorname{LogBB}^{f}$ & Levels & & & \\
\hline $6 a$ & 105.781 & 1.932 & 0 & -3.256 & 3 & -1.231 & 3 & 1 & 0 & 1 \\
\hline $6 b$ & 105.781 & 2.418 & 0 & -3.73 & 3 & -1.08 & 3 & 1 & 0 & 1 \\
\hline $6 c$ & 105.781 & 3.429 & 0 & -5.001 & 2 & - & 4 & 1 & 0 & 1 \\
\hline $6 d$ & 105.781 & 3.261 & 0 & -4.855 & 2 & - & 4 & 1 & 0 & 1 \\
\hline $6 e$ & 105.781 & 3.156 & 0 & -4.802 & 2 & - & 4 & 1 & 0 & 1 \\
\hline $6 \mathrm{f}$ & 105.781 & 2.669 & 0 & -4.337 & 2 & - & 4 & 1 & 0 & 1 \\
\hline
\end{tabular}

a Polar surface area (PSA) (>150: very low absorption).

${ }^{\mathrm{b}}$ A tom-based $\log \mathrm{P}$ (Alog P98) ( $\leq-2.0$ or $\geq 7$ : very low absorption).

${ }^{c}$ Level of human intestinal absorption prediction; 0 (good), 1 (moderate), 2 (poor), 3 (very poor).

${ }^{d}$ The based ${ }^{10} \log$ arithm of the molar solubility $\log (\mathrm{Sw})\left(25^{\circ} \mathrm{C}, \mathrm{pH}=7.0\right)$ (acceptable drug -like compounds: $\left.-6<\log (\mathrm{Sw}) \leq 0\right)$.

e Level of aqueous solubility prediction; 0 (extremely low), 1 (very low), 2 (low), 3 (good), 4 (optimal), 5 (too soluble), 6 (warning: molecules with one or more unknown Alog P calculation).

f Very high penetrants $(\log B B P \geq 7)$.

g Level blood brain barrier penetration prediction; 0 (very high penetrate), 1 (high), 2 (medium), 3 (low), 4 (undefined).

h Prediction Plasma-protein binding (0:<90\%; 1 $290 \%$;).

i Prediction cytochrome P4502D6 enzyme inhibition (0: non-inhibitor; 1 : inhibitor).

j Prediction hepato toxicity (0:non-toxic; 1 : toxic). 


\section{Materials and Methods}

Starting materials and chemical reagents were purchased from Sigma-Aldrich and Merck, and they were used without purification. Tetrahydrofuran (THF) was dried and distilled before use. The chemical reactions were routinely checked on Merck TLC plate silica gel $60 \mathrm{~F}_{254}$ in every reaction step. Purification procedures were conducted using column chromatography on Merck silica gel 60 (mesh 230-400). Melting points were taken on an Electrothermal 9100. IR spectra were measured on a Perkin Elmer Spectrum $400 \mathrm{FT}-\mathrm{IR} / \mathrm{FT}-\mathrm{NIR}$ with spotlight 400 Imaging system spectrometer. ${ }^{1} \mathrm{H}$ and ${ }^{13} \mathrm{C}$ NMR spectra were measured on a Bruker Avance III HD at 400 and $100 \mathrm{MHz}$, respectively. Mass spectra were obtained using Agilent 7890A. Electrospray ionization mass spectrometry w as conducted using Dionex Ultimate 3000 and Bruker Daltonic/MicroTOF Q. Spectrophotometric analy sis w as performed using an EPOCH (Biotek, USA) for antioxidant assay and SPECTROstar Nano BMG LabTech for inhibitory activities of AChE and BChE.

\subsection{General procedure for the synthesis of compound $2 b-2 e$}

A solution of salicylaldehyde (10 mmol, $1.220 \mathrm{~g})$, ethyl acetoacetate $(10 \mathrm{mmol}, 1.160 \mathrm{~g})$ and piperidine ( 3 to 4 drops) were magnetically stirred for 15 minutes to 24 hours. Then, the precipitate was filtered and washed with cold ethanol (10 $\mathrm{mL})$ to afford pure 3-acetylcoumarin [27].

\subsection{General procedure for the synthesis of compound $3 b-3 e$}

A mixture of 3-acetylcoumarin derivatives $(10 \mathrm{mmol}, 1.880 \mathrm{~g})$, NBS $(11 \mathrm{mmol}, 1.958 \mathrm{~g})$ and $p$ toluenesulfonic acid (1 mmol, $172 \mathrm{mg})$ in chloroform: acetonitrile (25:5) was magnetically stirred at reflux. After completion of the reaction [about $4 \mathrm{~h}$; TLC (Hexane/Ethyl acetate at a ratio of 9:1)], the mixture was cooled, and the precipitate was filtered and washed with ethanol $(10 \mathrm{~mL})$ to afford the pure product 3-(2-bromoacetyl) coumarin derivatives [28].

\subsection{General procedure for the synthesis of compound $4 a-4 e$}

The appropriate 3-(2-bromoacetyl)-2H-chromen-2-one $(1 \mathrm{mmol})$ and selenourea $(1 \mathrm{mmol})$ were dissolved in methanol: water $(2 \mathrm{~mL}: 2 \mathrm{~mL})$ containing $0.02 \mathrm{~g}$ of NaF. The mixture was magnetically stirred at room temperature for 15 to 30 minutes. After completion of the reaction, $5 \mathrm{~mL}$ of $\mathrm{w}$ ater was added, and the crude product was filtered and washed with water. Then, the crude product was extracted with ethyl acetate to yield pure substituted 1,3-selenazoles $[29,36]$.

\subsection{General procedure for the synthesis of compound $5 \boldsymbol{a}-5 \mathbf{d}$}

Isocyanate derivatives $(1 \mathrm{mmol})$ were added to a solution of $4 \mathbf{a}-4 \mathbf{e}(1 \mathrm{mmol})$ and triethylamine $(1 \mathrm{~mL})$ in dry THF. The mixture was refluxed under $\mathrm{N}_{2}$ atmosphere for 12 hours with stirring, then cooled and evaporated to dryness. The crude product was washed with chloroform and dried under vacuum [3]. The products were recrystallized from THF to obtained 40-60\% yields.

4.4.1. 1-(2-Chloro-phenyl)-3-[4-(2-oxo-2H-chromen-3-yl)-selenazol-2-yl]-urea (5a)

Pale yellow needle crystal; 0.27 g; Yield 60\%; Mass calculated: 445.9811; Mass found: 445.9702. ${ }^{1 H}$ NMR $(400 \mathrm{MHz}, \mathrm{THF}-\mathrm{d}) \delta ; 7.03(\mathrm{td}, 1 \mathrm{H}, J=7.7,1.3 \mathrm{~Hz}),, 7.29(\mathrm{td}, 2 \mathrm{H}, J=6.1,1.2 \mathrm{~Hz}), 7.34(\mathrm{dd}, 1 \mathrm{H}, J=7.2,2.4$ $\mathrm{Hz}), 7.41(\mathrm{dd}, 1 \mathrm{H}, J=8.0,1.2 \mathrm{~Hz}), 7.59(\mathrm{td}, 1 \mathrm{H}, J=7.8,1.6 \mathrm{~Hz}), 7.60(\mathrm{dd}, 1 \mathrm{H}, J=7.8,1.4 \mathrm{~Hz}), 8.26(\mathrm{~s}, 1 \mathrm{H}), 8.40$ $(\mathrm{dd}, 1 \mathrm{H}, J=8.2,1.4 \mathrm{~Hz}), 8.60(\mathrm{~s}, 1 \mathrm{H}), 8.69(\mathrm{~s}, 1 \mathrm{H}), 10.67$ (s, 1H). ${ }^{13} \mathrm{C} \mathrm{NMR}\left(100 \mathrm{MHz}, \mathrm{THF}-d_{8}\right) \delta ; 115.9$, $119.5,119.8,121.0,122.0,122.1,123.6,124.1,127.5,128.0,129.0,130.9,135.5,137.8,143.6,151.5,153.1$, $158.4,160.3$.

4.4.2. 1-(2-Bromo-phenyl)-3-[4-(2-oxo-2H-chromen-3-yl)-selenazol-2-yl]-urea (5b)

Pale yellow needle crystal; $0.10 \mathrm{~g}$; Yield $40 \%$; m: 230-231 ${ }^{\circ} \mathrm{C}$; Mass calculated: 489.9306; Mass found: 489.9312. ${ }^{1} \mathrm{H}$ NMR $\left(400 \mathrm{MHz}, \mathrm{THF}-d_{8}\right) \delta ; 6.97(\mathrm{td}, 1 \mathrm{H}, J=7.6,1.6 \mathrm{~Hz}), 7.28(\mathrm{td}, 1 \mathrm{H}, J=7.6,1.2 \mathrm{~Hz}), 7.34(\mathrm{ddd}$, $2 \mathrm{H}, J=7.3,1.8 \mathrm{~Hz}$ ), $7.53(\mathrm{ddd}, 1 \mathrm{H}, J=7.8,1.6,0.8 \mathrm{~Hz}), 7.59(\mathrm{td}, 2 \mathrm{H}, J=8,1.6 \mathrm{~Hz}), 8.12(\mathrm{~s}, 1 \mathrm{H}), 8.34(\mathrm{dd}, 1 \mathrm{H}$, 
$J=8.4,1.6 \mathrm{~Hz}), 8.60(\mathrm{~s}, 1 \mathrm{H}), \quad 8.69(\mathrm{~s}, 1 \mathrm{H}), 10.78(\mathrm{~s}, 1 \mathrm{H}) .{ }^{13} \mathrm{C}$ NMR $\left(100 \mathrm{MHz}, \mathrm{THF}-d_{8}\right) \delta ; 112.7,115.9,119.5$, $119.8,121.6,122.0,124.1,124.3,127.9,128.1,130.9,132.3,136.6,137.8,143.6,151.6,153.1,158.4$.

4.4.3. 1-(2-Bromo-phenyl)-3-[4-(8-methyl-2-oxo-2H-chromen-3-yl)-selenazol-2-yl]- urea (5c) Yellow needle crystal; 0.12 g; Yield $49 \%$; Mass calculated: 503.9462; Mass found: $503.9486 .{ }^{1} \mathrm{H}$ NMR $\left(400 \mathrm{MHz}, \mathrm{THF}-d_{8}\right) \delta ; 2.45(\mathrm{~s}, 3 \mathrm{H}), 6.97(\mathrm{td}, 1 \mathrm{H}, J=8.0,1.6 \mathrm{~Hz}), 7.18(\mathrm{t}, 1 \mathrm{H}, J=7.6,7.2 \mathrm{~Hz}), 7.33(\mathrm{td}, 1 \mathrm{H}, J=8.4$ $\mathrm{Hz}), 7.38(\mathrm{~d}, 1 \mathrm{H}, J=7.6 \mathrm{~Hz}), 7.42(\mathrm{~d}, 1 \mathrm{H}, J=7.6 \mathrm{~Hz}), 7.57(\mathrm{dd}, 1 \mathrm{H}, J=8.0,1.2 \mathrm{~Hz}), 8.11(\mathrm{~s}, 1 \mathrm{H}), 8.35(\mathrm{dd}, 1 \mathrm{H}$, $J=8.4,1.6 \mathrm{~Hz}), 8.58(\mathrm{~s}, 1 \mathrm{H}), \quad 8.69(\mathrm{~s}, 1 \mathrm{H}), 10.78(\mathrm{~s}, 1 \mathrm{H}) .{ }^{13} \mathrm{C}$ NMR $\left(100 \mathrm{MHz}, \mathrm{THF}-d_{8}\right) \delta ; 14.3,112.7,119.3$, $119.5,121.6,121.7,123.7,124.3,125.2$, 125.7, 128.1, 132.1, 132.3, 136.7, 138.2, 143.6, 151.4, 151.6, 158.5, 160.4 .

4.4.4 . 1-(2-Nitro-phenyl)-3-[4-2-oxo-2 H-chromen-3-yl)-selenazol-2-yl] -urea (5d)

Yellow needle crystal; $28.3 \mathrm{mg}$; Yield 7 \%; Mass calculated: 457.0051; Mass found: 457.0009. ${ }^{1} \mathrm{H}$ NMR $\left(400 \mathrm{MHz}, \mathrm{THF}-d_{8}\right) \delta ; 7.22(\mathrm{td}, 1 \mathrm{H}, J=8.4,1.2 \mathrm{~Hz}), 7.32(\mathrm{td}, 1 \mathrm{H}, J=7.4,0.9 \mathrm{~Hz}), 7.36(\mathrm{~d}, 1 \mathrm{H}, J=8.0 \mathrm{~Hz}), 7.56$ $(\mathrm{td}, 1 \mathrm{H}, J=7.2 \mathrm{~Hz}), 7.63(\mathrm{dd}, 1 \mathrm{H}, J=7.6,1.2 \mathrm{~Hz}), 7.72(\mathrm{td}, 1 \mathrm{H}, J=8.0,1.5 \mathrm{~Hz}), 8.24(\mathrm{dd}, 1 \mathrm{H}, J=8.4,1.6 \mathrm{~Hz})$, $8.63(\mathrm{~s}, 1 \mathrm{H}), \quad 8.74(\mathrm{~s}, 1 \mathrm{H}), 8.77(\mathrm{dd}, 1 \mathrm{H}, J=8.4,0.8 \mathrm{~Hz}), 10.18(\mathrm{~s}, 1 \mathrm{H}), 11.42(\mathrm{~s}, 1 \mathrm{H}) .{ }^{13} \mathrm{C} \mathrm{NMR}(100 \mathrm{MHz}$, THF- $\left.d_{8}\right) \delta ; 115.9,119.7,119.8,121.1,122.0,122.3,124.1,125.4,128.0,130.9,135.2,135.3,136.9,137.9$, $143.6,151.8,153.2,158.4,160.4$.

4.5 General procedure for the synthesis of compound $\mathbf{6 a - 6 f}$

Maleic anhydride (2 mmol) was dissolved in THF. Then, compound $4 \mathbf{a}-4 \mathbf{d}(2 \mathrm{mmol}) \mathrm{w}$ as added, and the mixture was magnetically stirred for 3 hours. The precipitate was filtered to give a pure product with $86-100 \%$ yield.

4.5.1. 3-[4-(2-Oxo-2H-chromen-3-yl)-selenazol-2-ylcarbamoyl]-acrylic acid (6a)

Pale yellow crystalline solid; 0.75 g; Yield : $96 \%$; mp: 218-219 ${ }^{\circ}$ C; Mass calculated:390.9833; Mass found: 390.9847. ${ }^{1} \mathrm{H}$ NMR (400 MHz, DMSO-d6) $\delta ; 6.20(\mathrm{~s}, 1 \mathrm{H}), 6.51(\mathrm{~d}, 1 \mathrm{H}, J=11.8 \mathrm{~Hz}), 6.56(\mathrm{~d}, 1 \mathrm{H}, J=11.8 \mathrm{~Hz})$, $7.39(\mathrm{t}, 1 \mathrm{H}, J=7.4 \mathrm{~Hz}), 7.45(\mathrm{~d}, 1 \mathrm{H}, J=8.0 \mathrm{~Hz}), 7.63(\mathrm{t}, 1 \mathrm{H}, J=7.2 \mathrm{~Hz}), 7.80(\mathrm{~d}, 1 \mathrm{H}, J=7.2 \mathrm{~Hz}), 8.63(\mathrm{~s}, 1 \mathrm{H}), 8.66$ $(\mathrm{s}, 1 \mathrm{H}), 12.89$ (s, 1H). ${ }^{13} \mathrm{C}$ NMR $\left(100 \mathrm{MHz}, \mathrm{DMSO}-d_{6}\right) \delta ; 116.4,119.6,121.5,121.7,125.3,127.9,129.2,132.3$, $133.7,139.3,143.4,152.9,159.4,163.7,167.4,167.7$.

4.5.2. 3-[4-(8-Methyl-2-oxo-2H-chromen-3-yl)-selenazol-2-ylcarbamoyl]-acrylic acid (6b)

Yellow crystalline solid; 0.39 g; Yield: $97 \%$; mp: 146-148 ${ }^{\circ} \mathrm{C}$; Mass calculated: 404.9990; Mass found:

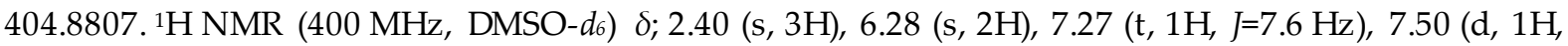
$J=7.2 \mathrm{~Hz}), 7.62(\mathrm{~d}, 1 \mathrm{H}, J=7.2 \mathrm{~Hz}), 8.03(\mathrm{~s}, 1 \mathrm{H}), 8.50(\mathrm{~s}, 1 \mathrm{H}) .{ }^{13} \mathrm{C}$ NMR (100 MHz, DMSO-d6) $\delta ; 15.4,113.8$, $119.3,119.9,121.4,124.9,125.3,126.9,130.7,133.4,140.0,143.4,151.1,159.3,167.2,167.8,170.5$.

4.5.3. 3-[4-(6,8-Dibromo-2-oxo-2H-chromen-3-yl)-selenazol-2-ylcarbamoyl]-acrylic acid (6c)

Pale yellow crystalline solid;0.27 g; Yield: $99 \%$; mp: 159-160 ${ }^{\circ} \mathrm{C}$; Mass calculated:546.8043; Mass found: 546.8046. ${ }^{1} \mathrm{H}$ NMR $\left(400 \mathrm{MHz}, \mathrm{DMSO}-d_{6}\right) \delta ; 6.26(\mathrm{~s}, 2 \mathrm{H}), 8.09(\mathrm{~s}, 1 \mathrm{H}), 8.23(\mathrm{~s}, 1 \mathrm{H}), 8.29(\mathrm{~s}, 1 \mathrm{H}), 8.41(\mathrm{~s}, 1 \mathrm{H})$. ${ }^{13} \mathrm{C}$ NMR $\left(100 \mathrm{MHz}, \mathrm{DMSO}-d_{6}\right) \delta ; 110.6,117.0,121.4,121.8,124.8,126.4,130.5,130.9,132.6,139.0,146.1$, $150.7,157.2,164.4,167.2,168.2$.

4.5.4. 3-[4-(6,8-Dichloro-2-oxo-2H-chromen-3-yl)-selenazol-2-ylcarbamoyl]-acrylic acid (6d)

Pale yellow crystalline solid; 0.23 g; Yield: $100 \%$; mp: 160-162 ${ }^{\circ} \mathrm{C}$; Mass calculated: 458.9054; Mass found: 458.9080. ${ }^{1} \mathrm{H}$ NMR $\left(400 \mathrm{MHz}, \mathrm{DMSO}-d_{6}\right) \delta ; 6.26(\mathrm{~s}, 2 \mathrm{H}), 7.89(\mathrm{~d}, 1 \mathrm{H}, J=2.4 \mathrm{~Hz}), 7.94(\mathrm{~d}, 1 \mathrm{H}, J=2.4$ $\mathrm{Hz}), 8.14(\mathrm{~s}, 1 \mathrm{H}), 8.47(\mathrm{~s}, 1 \mathrm{H}) ;{ }^{13} \mathrm{C}$ NMR $\left(100 \mathrm{MHz}, \mathrm{DMSO}-d_{6}\right) \delta ; 115.2,120.7,121.0,121.3,124.9,129.0$, $129.1,130.5,133.7,138.5,146.1,149.3,157.6,164.1,167.2,168.0$.

4.5.5. 2,3-Dichloro-3-[4-(8-methyl-2-oxo-2H-chromen-3-yl)-selenazol-2-ylcarbamoyl]-acrylic acid (6e) 
Pale yellow crystalline solid; 0.23 g; Yield: $98 \%$; mp: 175-177 ${ }^{\circ} \mathrm{C}$; Mass calculated: 472.9211;Mass found: 472.8690. ${ }^{1} \mathrm{H}$ NMR $\left(400 \mathrm{MHz}\right.$, DMSO- $\left.d_{6}\right) \delta ; 2.40(\mathrm{~s}, 3 \mathrm{H}), 7.27(\mathrm{t}, 1 \mathrm{H}, J=7.2 \mathrm{~Hz}), 7.49(\mathrm{~d}, 1 \mathrm{H}, J=6.8 \mathrm{~Hz}), 7.61$ $(\mathrm{d}, 1 \mathrm{H}, J=6.8 \mathrm{~Hz}), 8.60(\mathrm{~s}, 1 \mathrm{H}), 8.70(\mathrm{~s}, 1 \mathrm{H}), 13.31(\mathrm{~s}, 1 \mathrm{H}) .{ }^{13} \mathrm{C} \mathrm{NMR}\left(100 \mathrm{MHz}, \mathrm{DMSO}-d_{6}\right) \delta ; 15.4,119.3$, $121.1,121.9,124.9,125.3,127.0,128.5,131.0,133.5,134.7,140.0,151.2,159.4,161.2,161.7,162.4$.

4.5.6. 2,3-Dichloro-3-[4-(2-oxo-2H-chromen-3-yl)-selenazol-2-ylcarbamoyl]-acrylic acid (6f) Pale yellow crystalline solid; 0.20 g; Yield: $86 \%$; mp: $172-175^{\circ} \mathrm{C}$. ${ }^{1 \mathrm{H}} \mathrm{NMR}\left(400 \mathrm{MHz}, \mathrm{DMSO}-d_{6}\right) \delta ; 7.39$ $(\mathrm{t}, 1 \mathrm{H}, J=7.2 \mathrm{~Hz}), 7.45(\mathrm{~d}, 1 \mathrm{H}, J=8 \mathrm{~Hz}), 7.65(\mathrm{~d}, 1 \mathrm{H}, J=7.2 \mathrm{~Hz}), 7.80(\mathrm{~d}, 1 \mathrm{H}, J=7.2 \mathrm{~Hz}), 8.63(\mathrm{~s}, 1 \mathrm{H}), 8.70(\mathrm{~s}$, 1H), 13.34 (s, 1H). ${ }^{13} \mathrm{C}$ NMR (100 MHz, DMSO-d $)$ ) 8 ; 116.4, 119.5, 121.3, 122.1, 125.3, 129.2, 131.0, 132.4, $134.7,139.6,143.4,152.9,159.4,161.2,161.8,162.2$.

\subsection{Antioxidant activity assays}

In CUPRAC assay, the absorbance values were used to calculate for A0.50, but in DPPH and ABTS assay, inhibition (\%) values were used to calculate for $\mathrm{IC}_{50}$.

\subsubsection{DPPH a radical scavenging assay}

The DPPH radical scavenging assay of the derivatives $\mathrm{w}$ as measured according to the method reported previously with some modification [37]. Briefly, $1.5 \mathrm{~mL}$ aliquot of each sample at 16.125, 31.25, 62.50, 125 and $250 \mu \mathrm{g} / \mathrm{mL}$ was added to $1 \mathrm{~mL}$ of $0.1 \mathrm{mM}$ DPPH in methanol. The mixture was agitated vigorously for $1 \mathrm{~min}$ and allowed to stand in the dark for $90 \mathrm{~min}$ at room temperature. The absorbance value was recorded at $517 \mathrm{~nm}$. Gallic and ascorbic acids were used as a reference control. All measurements w ere carried out in triplicate. The radical scavenging assay of samples $w$ as expressed as percentage inhibition of DPPH using the following equation (1):

$$
\mathrm{I}(\%)=\left(\mathrm{A}_{c}-\mathrm{A}_{0} / \mathrm{A}_{c}\right) \times 100,
$$

Where $A_{c}$ is the absorbance value of the control (DPPH solution without samples); and $A_{0}$ is the absorbance value of the compound (DPPH solution with samples).

4.6.2. ABTS cation radical scavenging assay

ABTS scavenging activities of the synthesized compounds were determined according to the literature method [38]. The solution of ABTS radical was generated by dissolving $19.2 \mathrm{mg}$ of 2,2'-azino-bis(3ethylbenzothiazoline-6-sulphonic acid)(7 mM ABTS) and $3.3 \mathrm{mg} \mathrm{K} 2 \mathrm{~S}_{2} \mathrm{O}_{8}$ in distilled water $(5 \mathrm{~mL})$. The solution kept in the dark for $24 \mathrm{~h}$ at room temperature and their absorbance fixed to $0.70( \pm 0.02)$ at 734 $\mathrm{nm}$ by dilution. The stock solutions of the samples were prepared in methanol or 2-propanol at a concentration of $1000 \mu \mathrm{g} / \mathrm{mL}$. Then the samples were diluted to 500, 250, 125 and $62.5 \mu \mathrm{g} / \mathrm{mL}$. The absorbance was measured in room temperature at $734 \mathrm{~nm}$ after 10 minutes from ABTS addition. All measurements were carried out in triplicate. The results were calculated as IC 50.

\subsubsection{CUPRAC assay}

Cupric reducing antioxidant capacities of the synthesized compounds were determined according to the literature method [31]. The sample solutions and Trolox (standards) were prepared in methanol at a concentration of $1000 \mu \mathrm{g} / \mathrm{mL}$. Then, sample solutions were diluted to 500, 250, 125, 62.5, $31.25 \mu \mathrm{g} /$ $\mathrm{mL}$. Trolox solutions were diluted in the range of $1.0-62.5 \mu \mathrm{g} / \mathrm{mL}$. The addition of the solution is as follows: $1 \mathrm{~mL} \mathrm{Cu}(\mathrm{II})+1 \mathrm{~mL}$ neocuproin $+1 \mathrm{~mL}$ buffer solution $+1 \mathrm{~mL}$ sample/standard $+0.1 \mathrm{~mL} \mathrm{H}_{2} \mathrm{O}=$ $4.1 \mathrm{~mL}$. The absorbance was measured in room temperature at $450 \mathrm{~nm}$ after an hour. The res ults were calculated as A0.50. Methanol was used as a solvent to controls. 
$\mathrm{AChE}$ and BChE inhibitory activity of the compounds $\mathrm{w}$ as evaluated using Ellman's spectrometric assay following the conditions as described by Jamila et al. [32]. Electric eel AChE (Sigma Code: C2888) and equine serum BChE (Sigma Code: C7512) were used as the sources of cholinesterases, while acetylthiocholine iodide (Sigma Code: A5751) and S-butyrylthiocholine iodide (Sigma Code: 20820) were used as the sources of substrates. The enzymes were prepared at a concentration of $0.09 \mathrm{U} / \mathrm{mL}$ in $0.1 \mathrm{M}$ sodium phosphatebuffer ( $\mathrm{pH}$ 7.4). $14 \mathrm{mM} \mathrm{ATCI}$ BTCI solution w as prepared in deionized water while $10 \mathrm{mM}$ DTNB (Sigma Code: D218200) solution was prepared in phosphate buffer solution. Physostigmine (Sigma Code: E8375) was prepared in methanol at the initial concentration of $1 \mathrm{mg} / \mathrm{mL}$ and were diluted between 0 to $100 \mu \mathrm{g} / \mathrm{mL}$. Sample solutions were prepared by dissolving the sample in methanol or DMSO at the initial concentration of $1 \mathrm{mg} / \mathrm{mL}$, and it was diluted in a phosphatebuffer solution to the concentration of $2.5-100 \mu \mathrm{g} / \mathrm{mL}$. Next, $140 \mu \mathrm{L}$ of phosphate buffer solution, $20 \mu \mathrm{L}$ of test compounds or solvent and $20 \mu \mathrm{L}$ of the enzyme was firstly added to 96 -well microplate. The mixture was incubated at room temperature for 15 minutes. Then, $10 \mu \mathrm{L}$ DTNB and $10 \mu \mathrm{L}$ ATCI/BTCI was added to initiate the enzymatic reaction. The absorbance was measured at $412 \mathrm{~nm}$ using a microplate reader (SPECTROstar Nano, BMG LabTech, Offenburg, Germany). All reactions were carried out in triplicate. The IC 50 of compounds were calculated in $\mu \mathrm{M}$.

\subsection{Computational work}

All computational w orks were performed on a high-performance supercomputer of ServerWare Linux (Intel ${ }^{\circledR}$ Xenon $^{\circledR}$ six-core CPU ES-2620 v3 processor) (ServerWare Sdn. Bhd., Subang Jaya, Selangor, Malaysia) and supported with high-performance graphics processing unit (GPU), NVIDIA GeForce GTX 750 (NVIDIA, Santa Clara, California, USA).

\subsubsection{Ligands preparation}

The 2D structures of compounds $\mathbf{5 c}$ and $\mathbf{6 c}$ were drawn using MarvinSketch (ChemAxon Ltd., Budapest, Hungary) and converted to 3D structures in Maestro (Schrödinger, LLC, New York, USA). Before docking, these structures were geometrically optimized and minimized using OPLS3 in LigPrep (Schrödinger, LLC, New York, USA).

\subsubsection{Receptors preparation}

The crystal structures of human AChE (hAChE; PDB Code: 4EY7) and human BchE (hBChE; PDB Code: 5DYW) were obtained from the Protein Data Bank (PDB). The cholinesterase str uctures were prepared and optimized using the Protein Preparation Wizard (Schrödinger, LLC, New York, USA). All water molecules and cofactors were removed while mutation of incomplete amino acid residues and addition of missing residues was computed through Maestro and followed by minimizing the energy using Optimized Potentials for Liquid Simulations (OPLS3). Then, a receptor grid w as generated around the active site of AChE and BChE by choosing centroid of co-crystallized ligands of each enzyme which is donepezil for $4 \mathrm{EY7}$ and $\mathrm{N}$-\{[(3S)-1-benzylpiperidin-3-yl]methyl\}-N-(2-methoxyethyl)naphthalene-2sulfonamide for 5DYW. Grid box size was set to $20 \AA$ radius, using receptor grid generation implemented in Glide (Schrödinger, LLC, New York, USA).

\subsubsection{Molecular docking}

Molecular docking was carried out using Glide (Schrödinger, LLC, New York, USA). All docking calculations were performed using Extra Precision (XP) mode, and the best-docked complex of each compound $w$ as determined based on the Glide docking score. The interactions of the docked structures were further analyzed and visualized using PyMOL (Schrödinger, LLC, New York, USA).

\subsection{Data analysis}

Data were subjected to one-way analysis of variance (ANOVA) using SPSS software package for windows (IBM SPSS Statistics 25). The IC 50 (AChE) values were obtained from the plotted data using 
Microsoft Excel for Windows (Office 365). This study used $\alpha=0.05$. If the $P$-value $\leq \alpha$, there is enough evidence to conclude that the mean of IC 50 is different for the two compounds.

\section{Conclusions}

In summary, a series of novel coumaryl 1,3-selenazole derivatives (5a-5d and $\mathbf{6 a - 6 f}$ ) were synthesized, and their antioxidant activities and effects on AChE and BChE were evaluated in this study. Compounds tested demonstrated weak antioxidant activities and weak inhibition against $\mathrm{AChE}$ and $B C h E$. The IC $\mathrm{C}_{50}$ value for DPPH radical scavenging assay, ABTS cation radical scavenging assay and CUPRAC were $>300 \mu \mathrm{M},>1000 \mu \mathrm{M}$ and $>200 \mu \mathrm{M}$ respectively, which were high compared to the standards. The IC 50 values for $\mathrm{AChE}$ were reported between 56.01 and $221.35 \mu \mathrm{M}$, and the BChE value was observed, ranging from 121.34 to $311.37 \mu \mathrm{M}$. These IC 50 values were higher compared to positive controls (physostigmine) which exhibit IC 50 value of $10.12 \mu \mathrm{M}$ for AChE and $89.06 \mu \mathrm{M}$ for BChE. This is probably because the synthesized compounds are larger than previous w ork as it contains selenium which has bigger atomic size than sulfur making it challenging to bind in the binding pocket of AChE. However, the molecular docking studies of the most active inhibitor in each series, $\mathbf{5 c}$ and $\mathbf{6 b}$ compounds revealed that both displayed essential interactions with hAChE and hBChE. The overall findings suggested that coumaryl and phenyl moiety are crucial in forming $\pi-\pi$ stacking $w$ ith residues of hAChE and hBChE. Besides, the target moiety, selenazole ring, showed interaction only with residues of hBChE.

Supplementary Materials: The following are available online at $w w w . m d p i . c o m / x x x / s 1$, Figure S1: title, TableS1: title, Video S1: title.

Author Contributions: Conceptualization - N.Z.A. and N.I.H; methodology - N.Z.A, M.H.M.I, N.A.S.; molecular docking calculation - N.Z.A and M.H.M.I; molecular docking analysis was conducted by L.K.W and M.H.M.I; writing - original draft preparation, N.Z.A; writing - review and editing, N.Z.A, A.M.L and N.I.H; supervision, NI..H; project administration, S.H; data analysis, N.M. All authors have read and agreed to the published version of the manuscript.

Funding: Universiti Kebangsaan Malaysia funded this research, grant number GUP-2017-059. The graduate research assistant scheme (NZA) was funded by the Ministry of Higher Education, Malaysia (FRGS/1/2015/SG01/UITM/03/1).

Acknowledgements: The authors would like to thank the research facilities provided by the Department of Chemical Sciences, Faculty of Science \& Technology and Centre of Research and Instrumentation Management (CRIM), Universiti Kebangsaan Malaysia.

Conflicts of Interest: The authors declare no conflict of interest. 
19 of 22

\section{References}

1. Farzan, A.; Mashohor, S.; Ramli, A.R.; Mahmud, R. Boosting diagnosis accuracy of Alzheimer's disease using high dimensional recognition of longitudinal brain atrophy patterns. Behav. Brain Res. 2015, 290, 124-130.

2. Kumar, A.; Singh, A.; Ekavali A review on Alzheimer's disease pathophysiology and its management: An update. Pharmacol. Reports 2015, 67, 195-203.

3. Kurt, B.Z.; Gazioglu, I.; Sonmez, F.; Kucukislamoglu, M. Synthesis, antioxidant and anticholinesterase activities of novel coumarylthiazole derivatives. Bioorg. Chem. 2015, 59, 8090.

4. Więckow ska, A.; Więckow ski, K.; Bajda, M.; Brus, B.; Sałat, K.; Czerwińska, P.; Gobec, S.; Filipek, B.; Malawska, B. Synthesis of new N-benzylpiperidine derivatives as cholinesterase inhibitors with $\beta$-amyloid anti-aggregation properties and beneficial effects on memory in vivo. Bioorganic Med. Chem. 2015,23, 2445-2457.

5. Rosdinom Razali; Azlin Baharudin; Nik Ruszyanei Nik Jaafar; Hatta Sidi; Abdul Hadi Rosli; Khoo Boo Hooi; Lee Tyan Shin; Noor Hafizah Samsudin Bahari; Noralia Anis Elias Factors associated with mild cognitive impairment among elderly patients attending medical clinics in Universiti Kebangsaan Malaysia Medical Centre. Sains Malaysiana 2012,41, 641-647.

6. Razavi, S.F.; Khoobi, M.; Nadri, H.; Sakhteman, A.; Moradi, A.; Emami, S.; Foroumadi, A.; Shafiee, A. Synthesis and evaluation of 4-substituted coumarins as novel acetylcholinesterase inhibitors. Eur. J. Med. Chem. 2013, 64, 252-259.

7. Angona, I.P.; Daniel, S.; Martin, H.; Bonet, A.; Wnorowski, A.; Maj, M.; Józwiak, K.; Silva, T.B.; Refouvelet, B.; Borges, F.; et al. Design, Synthesis and Biological Evaluation of New Antioxidant and Neuroprotective Multitarget Directed Ligands Able to Block Calcium Channels. Molecules 2020, 25, 1-21.

8. Kashyap, P.; Kalaiselvan, V.; Kumar, R.; Kumar, S. Ajmalicine and Reserpine: Indole Alkaloids as Multi-Target Directed Ligands Tow ards Factors Implicated in Alzheimer's Disease. Molecules 2020, 25, 1609.

9. Öztürk, M. Anticholinesterase and antioxidant activities of Savoury (Satureja thymbra L.) with identified major terpenes of the essential oil. Food Chem. 2012, 134, 48-54.

10. Pereira, R.P.; Boligon, A.A.; Appel, A.S.; Fachinetto, R.; Ceron, C.S.; Tanus-Santos, J.E.; Athayde, M.L.; Rocha, J.B.T. Chemical composition, antioxidant and anticholinesterase activity of Melissa officinalis. Ind. Crops Prod. 2014, 53, 34-45.

11. Pourshojaei, Y.; Gouranourimi, A.; Hekmat, S.; Asadipour, A.; Rahmani-Nezhad, S.; Moradi, A.; Nadri, H.; Moghadam, F.H.; Emami, S.; Foroumadi, A.; et al. Design, synthesis and anticholinesterase activity of novel benzylidenechroman-4-ones bearing cyclic amine side chain. Eur. J. Med. Chem. 2015, 97, 181-189.

12. Júnior, J.T.C.; Morais, S.M. de; Vieira, L.G.; Alexandre, J. de B.; Costa, M. do S.; Morais-Braga, 
M.F.B.; Júnior, J.E.G.L.; Silva, M.M.O.; Barros, L.M.; Coutinho, H.D.M. Phenolic composition and anticholinesterase, antioxidant, antifungal and antibiotic modulatory activities of Prockia crucis (Salicaceae) extracts collected in the Caatinga biome of Ceará State, Brazil. Eur. J. Integr. Med. 2015, 7, 547-555.

13. Mao, F.; Chen, J.; Zhou, Q.; Luo, Z.; Huang, L.; Li, X. Novel tacrine-ebselen hybrids with improved cholinesterase inhibitory, hydrogen peroxide and peroxynitrite scavenging activity. Bioorganic Med. Chem. Lett. 2013, 23,6737-6742.

14. Tasso, B.; Catto, M.; Nicolotti, O.; Novelli, F.; Tonelli, M.; Giangreco, I.; Pisani, L.; Sparatore, A.; Boido, V.; Carotti, A.; et al. Quinolizidinyl derivatives of bi- and tricyclic systems as potent inhibitors of acetyl- and buty rylcholinesterase with potential in Alzheimer's disease. Eur. J. Med. Chem. 2011,46, 2170-2184.

15. Nam, S.O.; Park, D.H.; Lee, Y.H.; Ryu, J.H.; Lee, Y.S. Synthesis of aminoalkyl-substituted coumarin derivatives as acetylcholinesterase inhibitors. Bioorganic Med. Chem. 2014, 22, 12621267.

16. Jiang, Y.; Gao, H.; Turdu, G. Traditional Chinese medicinal herbs as potential AChE inhibitors for anti-Alzheimer's disease: A review. Bioorg. Chem. 2017, 75, 50-61.

17. Anand, P.; Singh, B.; Singh, N. A review on coumarins as acetylcholinesterase inhibit ors for Alzheimer's disease. Bioorganic Med. Chem. 2012,20, 1175-1180.

18. Piazzi, L.; Rampa, A.; Bisi, A.; Gobbi, S.; Belluti, F.; Cavalli, A.; Bartolini, M.; Andrisano, V.; Valenti, P.; Recanatini, M. 3-(4-\{[benzyl(methyl)amino]methyl\}-phenyl)-6,7-dimethoxy-2H-2chromenone (AP2238) inhibits both acetylcholinesterase and acetylcholinesterase-induced $\beta$ amyloid aggregation: A dual function lead for Alzheimer's disease therapy. J. Med. Chem. 2003, $46,2279-2282$.

19. Chekir, S.; Debbabi, M.; Regazzetti, A.; Dargère, D.; Laprévote, O.; Ben Jannet, H.; Gharbi, R. Design, synthesis and biological evaluation of novel 1,2,3-triazole linked coumarinopyrazole conjugates as potent anticholinesterase, anti-5-lipoxygenase, anti-tyrosinase and anti-cancer agents. Bioorg. Chem. 2018, doi:10.1016/j.bioorg.2018.06.005.

20. Alias, N.Z.; Wan Ahmad, W.Y.; Ismail, N.A.S.; Hassan, N.I. Novel Hybrid Molecules of Cholinesterase Inhibitor for Alzheimer's Disease : A Systematic Review. Res. J. Pharm. Biol. Chem. Sci. 2017, 8, 734-738.

21. Al-Amiery, A.A.; Al-Majedy, Y.K.; Kadhum, A.A.H.; Mohamad, A.B. Novel macromolecules derived from coumarin:Synthesis and antioxidant activity. Sci. Rep. 2015, 5, 1-7.

22. Ng, R.C.; Kassim, N.K.; Yeap, Y.S.Y.; Lian Ee, G.C.; Yazan, S.L.; Musa, K.H. Isolation of carbazole alkaloids and coumarins from Aegle marmelos and Murraya koenigii and their antioxidant properties. Sains Malaysiana 2018, 47, 1749-1756.

23. Alias, N.Z.; Hassan, N.I.; Yusoff, Z.; Hasan, S.; Ahmad, W.Y.W. Synthesis, Characterization and Antioxidant Activity of 3-(2-Amino-1,3-Selenazol-4-yl)-2H-Chromen-2-Ones Derivatives. Sains Malaysiana 2018, 47, 347-352. 
24. Bhabak, K.P.; Mugesh, G. Synthesis, characterization, and antioxidant activity of some ebselen analogues. Chem. - A Eur. J. 2007,13, 4594-4601.

25. Tinggi, U. Selenium: Its role as antioxidant in human health. Environ. Health Prev. Med. 2008, 13, 102-108.

26. Alias, N.Z.; Wan Ahmad, W.Y.; Hassan, N.I.; Yamin, B.M.; Ngatiman, M.F. Crystal structure of 3-(2-amino-1,3-selenazol-4-yl)-2H-chromen-2-one- Dimethylformamide (1/1), C15H15N3O3Se. Zeitschrift fur Krist. - New Cryst. Struct. 2017,232, 607-609, doi:1.

27. Jones, G. The Knoevenagel Condensation. In Organic Reactions; 1967; pp. 204-599.

28. Alizadeh, A.; Ghanbaripour, R. An efficient synthesis of pyrrolo[2,1-a]isoquinoline derivatives containing coumarin skeletons via a one-pot, three-component reaction. Res. Chem. Intermed. $2015,41,8785-8796$.

29. Banothu, J.; Vaarla, K.; Bavantula, R.; Crooks, P.A. Sodium fluoride as an efficient catalyst for the synthesis of 2,4-disubstituted-1,3-thiazoles and selenazoles at ambient temperature. Chinese Chem. Lett. 2014, 25, 172-175.

30. Koketsu, M.; Ishihara, H. 1,3-Selenazoles. In Reference Module in Chemistry, Molecular Sciences and Chemical Engineering Comprehensive Heterocyclic Chemistry III; 2008; pp. 791-821.

31. Güngör, N.; Özyürek, M.; Güclü, K.; Cekic, S.D.; Apak, R. Comparative evaluation of antioxidant capacities of thiol-based antioxidants measured by different in vitro methods. Talanta 2011, 83, 1650-1658.

32. Jamila, N.; Khairuddean, M.; Yeong, K.K.; Osman, H.; Murugaiyah, V. Cholinesterase inhibitory triterpenoids from the bark of Garcinia hombroniana. J. Enzyme Inhib. Med. Chem. 2015,30,133139.

33. Fadaeinasab, M.; A. Hadi, A.H.; Kia, Y.; Basiri, A.; Murugaiyah, V. Cholinesterase enzymes inhibitors from the leaves of rauvolfia reflexa and their molecular docking study. Molecules 2013, $18,3779-3788$.

34. Cheung, J.; Rudolph, M.J.; Burshteyn, F.; Cassidy, M.S.; Gary, E.N.; Love, J.; Franklin, M.C.; Height, J.J. Structures of Human Acetylcholinesterase in Complex with Pharmacologically Important Ligands. J. Med. Chem. 2012, 55, 10282-10286.

35. Rosenberry, T.L.; Brazzolotto, X.; MacDonald, I.R.; Wandhammer, M.; Trovaslet-Leroy, M.; Darvesh, S.; Nachon, F. Comparison of the binding of reversible inhibitors to human butyrylcholinesterase and acetylcholinesterase: A crystallographic, kinetic and calorimetric study. Molecules 2017,22, 2098.

36. Madhav, J.V.; Kuarm, B.S.; Rajitha, B. Solid-state synthesis of 1,3-selenazoles employing CuPy2Cl2 as a Lew is acid catalyst. Synth. Commun. 2008, 38, 3514-3522.

37. Mahdavi, B.; Yaacob, W.A.; Din, L.B.; Lee, Y.H.; Ibrahim, N. Chemical composition, antioxidant, and antibacterial activity of essential oils from Etlingera brevilabrum Valeton. Rec. Nat. Prod. 2016, 10, 22-31. 
38. Re, R.; Pellegrini, N.; Proteggente, A.; Pannala, A.; Yang, M.; Rice-Evans, C. Antioxidant activity applying an improved ABTS radical cation decolorization assay. Free Radic. Biol. Med. 1999, 26, 1231-1237. 